\title{
Use of Bone Layers to Determine Age in Minke Whales
}

\author{
L. I. SUKHOVSKAYA, G. A. KLEVEZAL, V. I. BORISOV \\ \& S. J. LAGEREV
}

Sukhovskaya L. I., Klevezal G. A., Borisov V. I. \& Lagerev S. I., 1985: Use of bone layers to determine age in minke whales. Acta theriol., 30, 17: 275-286 [With 3 Tables, 4 Figs. \& Plate III]

Examination was made of tympanic bullae and ear plugs from 43 minke whales Balaenoptera acutorostrata (Lacepéde, 1804) taken in the Antarctic in December 1980. The number of layers in acidetched polish sections was systematically underestimated as compared with those in haematoxylin-stained sections of the same bone segment. In stained sections the layers are distinct. except for one or two inner layers, the boundaries of which may be diffuse. The number of layers varies in different bone segments, being usually highest in the medial side, $15-20 \mathrm{~mm}$ from the middle toward the oral part. The actual age of an individual is most closely represented by the maximum number of layers in the tympanic bulla. The maximum number of layers varied from 5 to 25 , most frequently from 7 to 10 . The surface of the tympanic bulla on which the layers are formed seems to decrease considerably with age and therefore the maximum number of layers in this bone may be less than the true age of an individual. Determination of age from the number of layers in the tympanic bone requires further studies. No correlation was found between the number of layers in the bone and those in the ear plug. and it was therefore concluded that the latter does not form a reliable age criterion in Antarctic minke whales.

[Kolcov's Inst. of Developmental Biol., USSR Acad. Sci., 26 Vavilov Str., 117334 Moscow, USSR].

\section{INTRODUCTION}

Counting ear plug layers is a widely used method for determining age in baleen whales. Several techniques have been developed to reveal the ear plug layers (Tarasevič, 1971) but in practice many investigators count layers on longitudinal non-stained sections observed in reflected light. The age of an individual is estimated from the number of layers, each consisting of one light and one dark band, though opinions differ as to how many layers are formed during one year (Purves \& Mountford, 1959; Roe, 1967; Ichihara, 1966; van Utrecht \& van Utrecht-Cock, 1969).

In examining the structure of tympanic bullae from fin whales and sei whales on thin sections stained with haematoxylin, Klevezal \& Mitchell (1971) found that the number of layers in the periosteal zone of 
the medial wall of tympanic bulla increase with the whale's body size and in most cases correspond fairly well with age estimated approximately from the number of layers in the ear plug. These authors had only nine whales at their disposal. The three oldest fin whales differing in body length were found to have the same number of layers in the bone (10-11), and consequently those authors did not rule out the possibility that this may be the age limit at which the growth of the bone and the formation of new layers cease. Ten years later Christensen (1981) demonstrated the use of layers in the periosteal bone of the tympanic bulla for age determination of minke whales. He tried both the techniques of haematoxylin-stained and acid-etched sections and found the latter more satisfactory for revealing the layers. By relating the number of layers in the bone to those in the ear plugs, to body length and to the number of corpora lutea, Christensen (1981) concluded that layers in the periosteal zone of the bulla are formed annually.

The present work was started before Christensen's (1981) paper appeared and aimed at investigating the possibility of age determination in minke whales using layers in the periosteal zone of the tympanic bulla.

\section{MATERIAL AND METHODS}

The material used for the present study consisted of ear plugs and tympanic bullae from 43 minke whales taken in the Antarctic, Sector III, in December 1980. The bullae were stored dry and the ear plugs were fixed in $10 \%$ formalin. Using a cutting machine with a diamond disk, $3-5 \mathrm{~mm}$ thick segments were cut out from the medial side of the tympanic bulla of each whale (Fig. 1A). The segments were decalcified in $5 \%$ nitric acid for $2-3$ days and washed in running water for 12-24 hours. Freezing microtome sections of $20-30$ microns were stained with Ehrlich's 'haematoxylin and mounted in glycerine. In a similar manner different segments of the ventral and dorsal sides were examined in seven whales and all the segments of the medial side in one whale (Fig. 1).

The tympanic bullae from eight whales were cut transversely along the median line and a segment of the medial side was taken from one half to prepare stained sections, while the other half was polished along the cutting line and the polished surface was etched in $10 \%$ formic acid for 20 minutes, washed and dried, i. e. prepared in the manner suggested by Christensen (1981).

The ear plugs fixed in formalin on board of whaler were washed in running water for $12-24$ hours. Freezing microtome longitudinal sections, $15-30$ microns thick, were stained with haematoxylin-sudan (according to Daddy) and mounted in glycerine.

Counts of layers in the stained sections of the bone and the ear plugs were made independently by three operators, using a dissecting microscope and a microscope with transmitted light. One layer was taken to consist of one dark and one light band in the plug section and of one light tissue layer bounded by a dark adhesion line in the bone section. Two operators (A and B) had some 
experience in counting annual layers in the bone, but were faced with the task of doing so in ear plugs for the first time. One operator (C) was experienced in counting layers in non-stained ear plugs, but had no experience with stained sections.

\section{RESULTS}

Out of 27 ear plugs, non-stained sections of which were examined in reflected light on board, 15 proved to be unreadable (Table 1). On six stained sections out of 22 , the layers could not be counted by one or all of the operators.

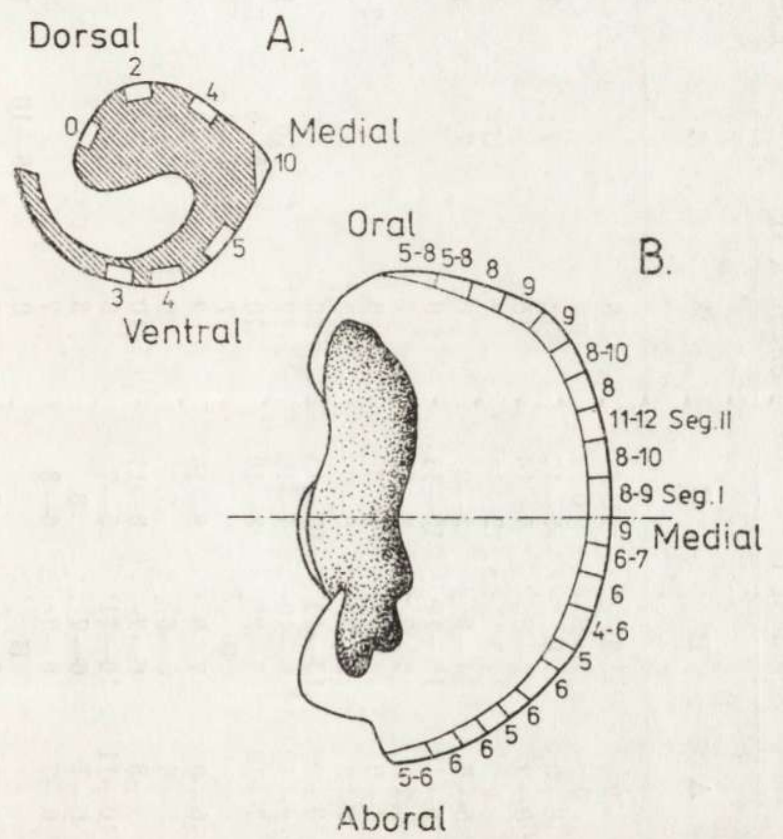

Fig 1. Schematic drawing of tympanic bulla from minke whale: A - transversal section through the middle of the bone (animal no 15, Table 1), B - (animal no 3, Takle 1) tympanic bulla with different segments of medial side taken for examination. Dotted line shows a level of transversal section through the middle of the bone.

A distinct tendency was observed to reveal a much greater number of layers in non-stained than in stained sections of the ear plug. A comparison of counts by operator $\mathrm{C}^{1}$ gave the following results for the same whales:

${ }^{1}$ Counts in non-stained sections made by operator $\mathrm{C}$ or by other biologists of the research team during whaling. 


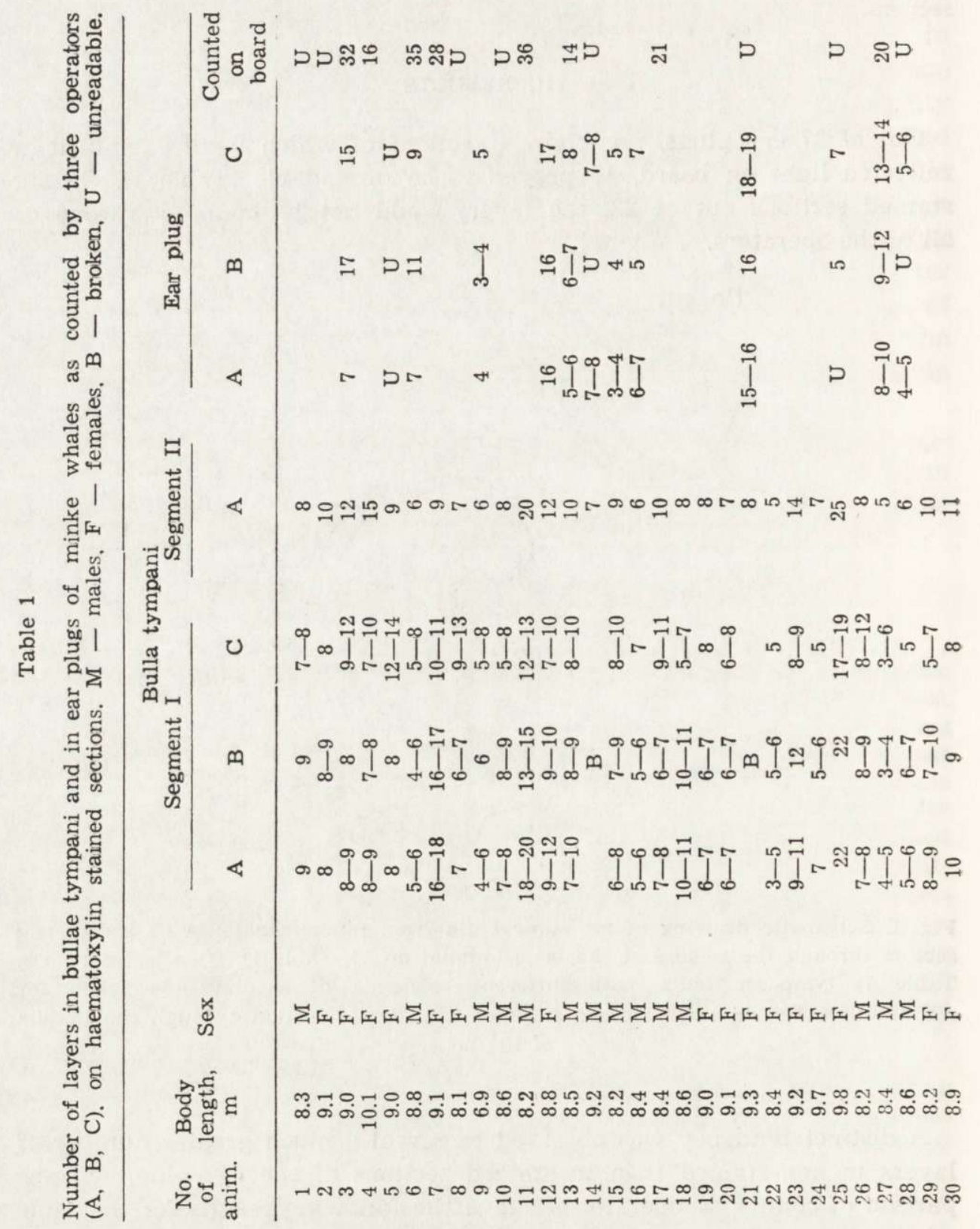




$$
\begin{aligned}
& \text { D }
\end{aligned}
$$

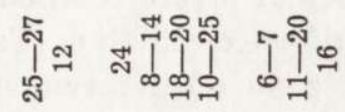

$$
\begin{aligned}
& \text { โิ }
\end{aligned}
$$

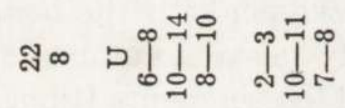

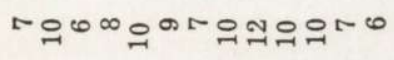

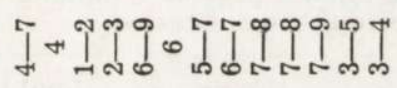

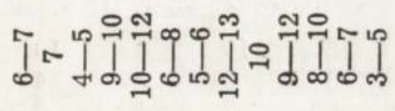

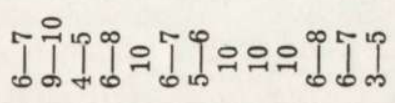

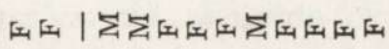

ஸิ

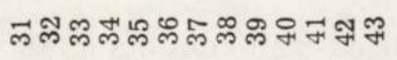


Stained sections

Non-stained sections
15

$32 \quad 35$

$\begin{array}{llllll}9 & 8 & 14 & 14 & 20 & 20 \\ 14 & 20 & 21 & 26 & 48\end{array}$

Layer counts in stained ear plug sections made by three operators differed significantly. In seven cases out of twenty one, the maximum number of layers counted was twice higher than the minimum number for the same animal. The number of layers counted was the same whichever section of a plug was taken for examination (Table 1).

The layers in the periosteal zone of the tympanic bulla are clearly defined (Phot. 1, Plate III). The boundary between the periosteal and the mesosteal zones is not clearly defined while the inner layers are wider than the outer. The first and sometimes also the second inner layers are often indistinguishable, their boundary appearing as a somewhat diffuse line (Phot. 1). In those segments of the bone where the periosteal zone forms folds, a significantly greater number of narrow outer layers were found than in the non-folded segments (Phot. 2, Plate III).

In 41 cases the layers in the middle of the medial side (Segment I) were counted by three operators (Table 1). In nine of them the counts

\section{Table 2}

Maximum number of layens in the periosteal zone of different segments in the middle part of tympanic bulla. Seven specimens were tested.

\begin{tabular}{lrrrrrrr}
\hline \multirow{2}{*}{ Segment } & \multicolumn{7}{c}{ Number of animal ${ }^{1}$} \\
& 2 & 3 & 4 & 6 & 15 & 18 & 35 \\
\hline Medial side & 9 & 12 & 10 & 8 & 10 & 11 & 12 \\
Dorsal side & 5 & 6 & 6 & 2 & 4 & 5 & 4 \\
Ventral side & 7 & 8 & 7 & 4 & 5 & 7 & 7 \\
\hline
\end{tabular}

${ }^{1}$ cf. Table 1

- of all the operators coincided or were very close each to each other. In 23 out of 41 cases the counts made by two operators were the same. Differences of 1-2 layers were observed in 16 cases and of 3 and more layers in 17 cases. The counts obtained by operators A and B were sometimes almost twice as high as counts by operator C. It appeared, however, that the operators had counted the layers in different sections. The distribution of animals by the number of layers in Segment I (Fig. 2) shows that only three animals had 18-22 layers, the rest had 5 to ,12 layers.

As the results obtained aroused some doubts as to whether the segment of the tympanic bulla chosen was the best for counting the layers, various segments of the dorsal and ventral sides from the middle tympanic bulla were taken for examination in seven animals, and all the segments of 
the medial side in one animal. In the latter case each tenth section was taken from the oral to the aboral part of the bone (Fig. 1B). The maximum number of layers was seen in the medial side, i. e. in the segment taken for examination from all the animals (Fig. 1B, Table 2). With increasing distance of the segment from the medial wall the number of layers decrease, in both the dorsal and ventral sides. The segment with the highest number of layers, however, was that situated $15-20 \mathrm{~mm}$ toward

Table 3

Number of layers in the middle part of the medial wall of tympanic bulla (segment I) revealed in stained sections and etched polished sections by operator $\mathrm{A}$.

\begin{tabular}{ccc}
\hline Animal number & Stained sections & Etched sections \\
\hline 11 & $18-20$ & $6-7$ \\
23 & $9-11$ & $5-6$ \\
25 & 22 & $7-8$ \\
32 & $9-10$ & $3-4$ \\
35 & 10 & $3-4$ \\
36 & $6-7$ & $5-6$ \\
38 & 10 & $7-9$ \\
39 & 10 & $6-7$ \\
40 & 10 & $6-7$ \\
41 & $6-8$ & \\
\hline
\end{tabular}
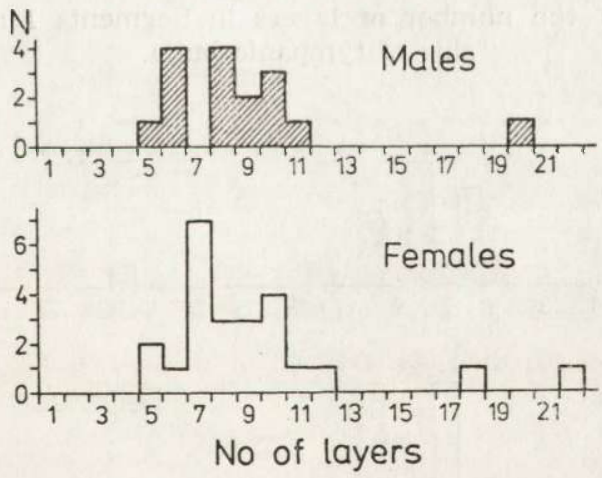

Fic. 2. Distribution of animals by the number of appositional bone layers in the middle of the medial side of tympanic bulla (Segment I).

the oral part (Segment II) rather than that in the middle (Segment I) (Fig. 1B). This segment was taken for additional examination in all 43 animals and the results are given in Table 1. Except for three cases when the number of layers was lower in Segment II than in Segment I, the number of layers was lower in Segment II than in Segment I, the number of layers in Segment II was equal to or higher than that in Segment 
I. The following tendency was observed: most of the animals with 5-7 layers in the middle of the wall had the same number of layers in Segment II, while most of the animals with eight or more layers in the middle of the medial wall (Segment I) had a higher number of layers in Segment II (Fig. 3).

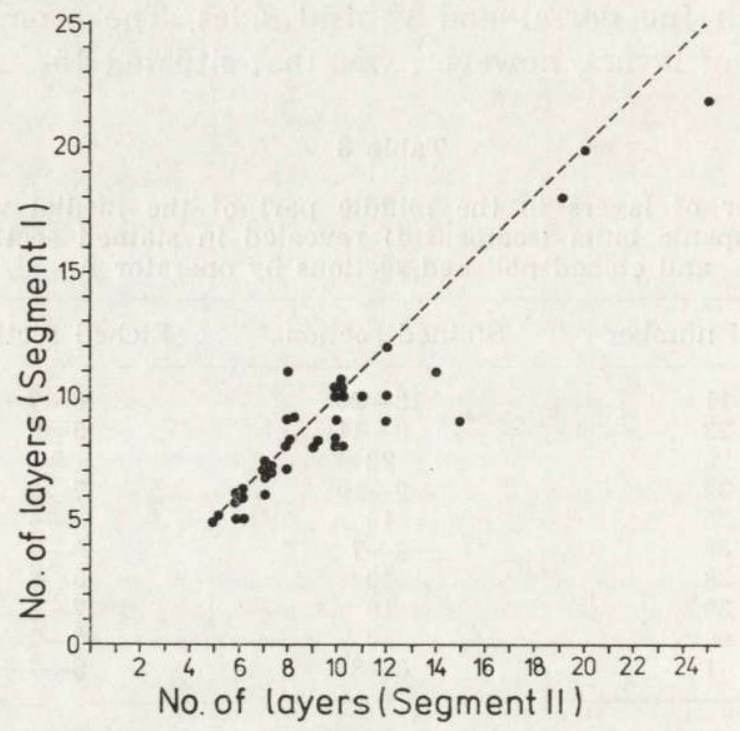

Fig. 3. Relationship of the number of layers in Segments I and II of the medial side of tympanic bulla.
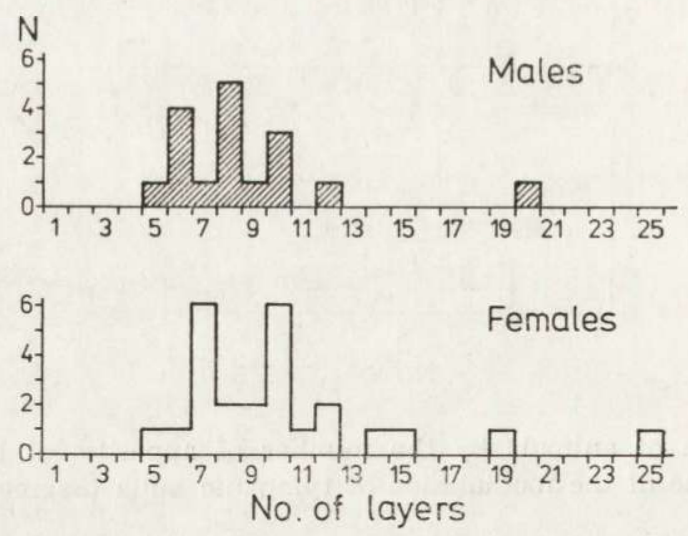

Fig. 4. Distribution of animals by the number of layers in the medial side segment of tympanic bulla (Segment II), situated $15-20 \mathrm{~mm}$ orally from the middle.

The greatest number of animals have 7-10 layers in both segments, but counts made in Segment II revealed animals with 12-15 layers (Fig. 4). 
The tympanic bullae prepared according to Christensen (1981) revealed roughly the same number of layers in the section after etching as could be seen in the reflected light before etching. The inner layers could be seen better and the outer layers were more difficult to see. The total number of layers revealed was considerably lower than that in stained sections (Table 3 ).

Comparison of the number of layers in ear plugs (as counted by operator C) with the number of layers in the middle of the medial wall (Segment I), and in Segment II of the bone, did not reveal any correlation in either of the cases (Table 1).

\section{DISCUSSION}

Larsen (1981) tried to determine the age of minke whales by counting layers in acid-etched sections of tympanic bullae, but did not obtain satisfying results. In the present paper it was found that the method gave systematically lower results than counts of bone layers on sections stained with haematoxylin. In this case the layers in the periosteal zone are seen fairly distinctly, except for one or two inner layers, the boundary of which is often diffuse. A major difficulty in counting the layers in these sections is that the number of layers may be different in various segments of the same bone, in various sections of the same segment and in various parts of the same section. Basically, this may happen: (1) when the appositional growth of the bone discontinues at a relative early age in some segments and is continued in other segments where new layers are formed, and (2) if the annual bone increment is locally very high and not only annual but also additional layers are formed which we cannot discriminate annual ones. The true age of the animal is more consistent with the maximum number of bone layers counted in the first instance and with the minimum in the second. A satisfying answer to the question as to which of the two situations we are dealing with could be supplied by study of animals of known age. Though no material of this kind is available we have some indirect data. A study of ground squirrels (Spermophilus undulatus) showed that the tympanic bullae grow annually for a shorter period than other bones of the skeleton and this period continually decreases with age (Klevezal, 1978). If the growth of the tympanic bullae in baleen whales follows the same pattern of negative allometry, we can hardly expect high annual bone increments where additional layers could be formed, but is is not improbable that the bone surface available for appositional growth decreases with age. Some evidence in favour of this speculation is provided by comparison of the number of layers in different segments of the medial wall of the 
tympanic bulla. In most cases the number of layers in Segments I and II were the same, but the differences in the numbers between these segments increased with increasing number of layers (Fig. 3). It is likely that after the formation of seven layers "the growing surface", on which the layers are formed, decreases progressively. Consequently, the older the animal, the smaller the bone surface available for layer formation. So that the true age of an animal is more consistent with the maximum number of layers counted in the bone.

Our material did not show any correlation between the number of layers in the bone and that in the ear plug, while Christensen (1981) demonstrated a fairly good correlation of these data for minke whales from the Barents Sea. This may be due to inadequacy of ear plugs as a criterion for age determination of Antarctic minke whales. Our limited amount of material showed appreciable differences in the counts of plug layers between different operators, even when stained sections were used. According to Best (1982) ear plugs can be extracted from only $54 \%$ of the minke whales taken in the south-western Indian Ocean and only $51 \%$ of these plugs could be used for counting in stained sections. Mihalev (1984), who examined minke whales from Antarctic waters, concluded that "waste" while using ear plugs for age determination amounted on the whole to no less than $80 \%$.

The limited material examined by us shows that most of the animals had 7-10 layers in the bone, though some had as many as 25 and some as few as 5 layers. Christensen (1981) examined 316 animals from the Barents Sea. The number of layers in the animals of his sample ranged from 2 to 25, but most of the animals had 4-7 layers. Assuming that the number of layers in the bone corresponds to the age of the animals in years, it must be admitted that comparatively young animals were predominant in both the samples examined. The absence of animals below 5 years old in our material is undoubtedly a consequence of selective hunting for larger individuals. On the other hand, there was a small number of animals more than 11 years old and complete absence of animals over than 25 years old. This is inconsistent with data by Mihalev (1984), who showed that the average age of minke whales harvested in the Antractic in 1972-1980 was 19-24 years for females and 18-20 years for males. Mihalev's (1984) data on the age of animals were based on the number of layers in ear plugs and therefore could have been overestimated. What is much more important is that according to annual IWC reports, the abundance of minke whales in the Antarctic has not been decreasing but even increasing recently and therefore the small number of animals over 11 years old in our sample seems to be peculiar.

The possibility cannot be ruled out that the area of the tympanic bulla 
available for bone tissue apposition decreases with age to such an extent that the place with the highest number of layers may be overlooked. It is also possible that on reaching a certain age the apposition of the bone tissue terminates completely. As ear plug layers do not constitute too reliable a criterion of age in the Antarctic minke whale, it would be reasonable to develop a method based on layered structure of bones, not restricting ourselves to the tympanic bulla alone.

Studies of the process of annual layer formation in the bones of aquatic and terrestrial mammals suggested that in animals as large and as fastgrowing as baleen whales, the annual layers in the periosteal bone should be looked for in bones showing negative allometry of growth during the post-natal period (Klevezal, 1972). The bones of this type grow fast during the pre- and early post-natal periods, then their growth rate slows down and for a long period continues to be much lower than the growth rate of main skeleton bones, which creates conditions for the formation and retention of annual layers. The tympanic bulla is not the only skull bone of baleen whales characterized by negative allometry. It would seem to be worth-while to study other bones of this group in the hope of finding one where the process of annual layer formation might go on until a later age and might extend over a larger area of the bone surface than in the tympanic bulla.

Acknowledgements: We wish to thank Dr. M. V. Ivashin for his critical reading of this paper.

\section{REFERENCES}

1. Best P. B., 1982: Seasonal abundance, feeding, reproduction, age and growth in minke whales off Durban (with incidental observations from the Antarctic). Rep. Int. Whal. Comm., 32: 759-793.

2. Christensen I., 1981: Age determination of minke whales, Balaenoptera acutorostrata, from laminated structures in the tympanic bullae. Rep. Int. Whal. Comm., 31: 245-253.

3. Ichihara I., 1966: Criterion for determining age of fin whale with reference to ear plug and baleen plate. Sci. Rep. Whale Res. Inst., 20: 17-82.

4. Klevezal G. A., 1972: On the relationship between the growth rate of the animal and formation of annual layers in mammal bone. Ž. Obšc. Biol., 33: 166-175 [In Russian with English summ.].

5. Klevezal G. A., 1978: Age patterns of seasonal rhythm of the growth of skeleton in the long-tailed Siberian souslik. Zool. Ž., 57: 917-922 [In Russian with English summ.].

6. Klevezal G. A. \& Mitchell E., 1971: Year layers in bones of whale bone whales. Zool. Ż., 50: 1114-1116 [In Russian with English summ.].

7. Larsen F., 1971: Reproductive parameters of the minke whale, Balaenoptera acutorostrata, at west Grenland, Denmark. Abstracts of Conference "Cetacean reproduction: estimating parameters for stock assessment and management, La Jolla, California, Nov. 28 - Dec. 7 1981, p. 23. 
8. Mihalev Ju. A., 1984: [Growth and some aspects of breeding biology of the Southern Hemisphere minke whale.] In collected papers: "Marine mammals" Nauka: $61-81$, Moskva [In Russian].

9. Purves P. E. \& Mountford M. D., 1959: Ear plug laminations in relation to the age composition of a population of fin whales. Bull. Brit. Mus. Nat. Hist. Zool., 5, 6: 123-161.

10. Tarasevič M. N. (compiler), 1971: [Procedure for age determination in baleen whales from ear plugs and in toothed whales from jaws and teeth]. VNIRO: $1-40$, Moscow [In Russian].

11. Roe H. S. J., 1967: Seasonal formation of laminae in the ear plug of the fin whale. Discovery Rep., 35: 1-30.

12. Utrecht W. L., van \& van Utrecht-Cock C. N., 1969: Comparison of records of baleen plants and ear plugs in female fin whales, Balaenoptera physalus (Linnaeus, 1758). Bijdr. Dierkunde, 39: 81-97.

Accepted, February 25, 1985.

L. I. SUKhovskaya, G. A. KLeVEZAL, V. I. BORISOV i S. I. LAGEREV

\author{
OKRESLENIE WIEKU PEETWALA KAREOWATEGO, \\ BALAENOPTERA ACUTOROSTRATA \\ NA PODSTAWIE WARSTW KOSCI
}

Zbadano puszki bębenkowe i czopy uszne (ear plug) 43 płetwali karłowatych. Liczba słoi kości puszki bębenkowej określana na skrawkach trawionych kwasem była systematycznie zaniżana w porównaniu z preparatami barwionymi hematoksy1iną. Na tych ostatnich wszystkie linie sklejania kości byly dobrze widoczne, z wyjątkiem jednej lub dwu linii wewnętrznych (Ryc. 2 i 3). W różnych segmentach kości puszki bębenkowej stwierdzono różną liczbę słoi (Ryc. 1), zwykle najwyższą od strony przyśrodkowej. Największa liczba warstw kości puszki bębenkowej jest najbardziej zgodna $\mathrm{z}$ rzeczywistym wiekiem waleni. Wydaje się, że powierzchnia puszki bębenkowej, na której tworzą się słoje kości, zmniejsza się z wiekiem i dlatego maksymalna liczba słoi może być niższa niż liczba lat życia walenia. Nie stwierdzono zależności między liczbą słoi w kości puszki bębenkowej i w czopie usznym, a zatem ten ostatni nie może być używany do określenia wieku waleni.

\title{
EXPLANATION OF PLATE III
}

Phot. 1. Cross section of the medial side of tympanic bulla; haematoxylin stained; magnification $30 \times$; arrows show layers (Female no 25, Table 1).

Phot. 2. Segment of cross section of the medial side of tympanic bulla; haematoxylin stained; magnification $30 \times$. A - segment with changed direction of layer apposition (Male no 11, Table 1). 

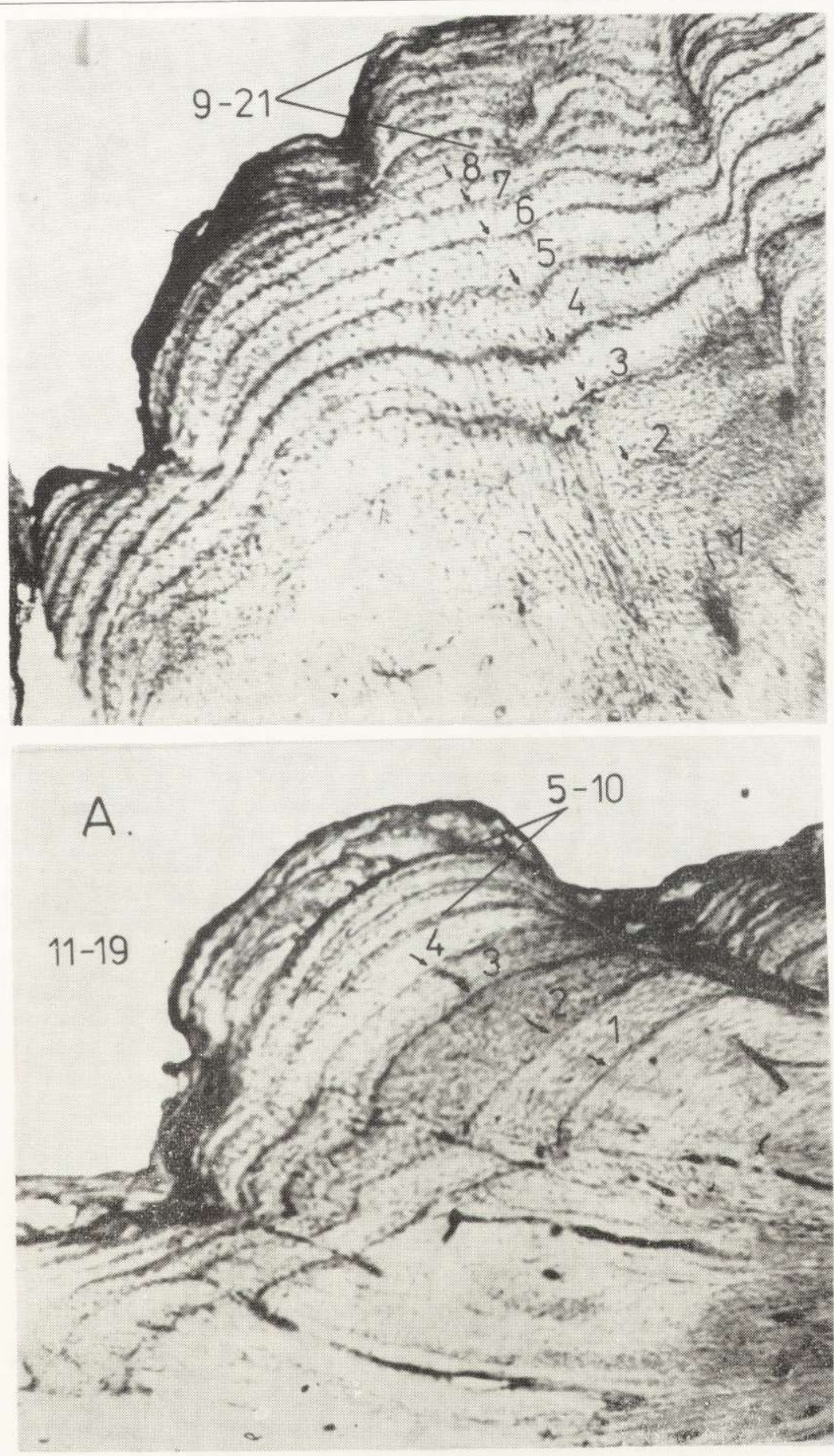

L. I. Sukhovskaya et al. 